\title{
Synthesis of Calcium-Phosphate and Chitosan Bioceramics for Bone Regeneration
}

\author{
MELLATIE R. FINISIE, ATCHE JOSUÉ, VALFREDO T. FÁVERE and MAURO C. M. LARANJEIRA \\ Departamento de Química, Universidade Federal de Santa Catarina, \\ Campus Universitário, Trindade - 88040-900 Florianópolis-SC, Brazil. \\ Manuscript received on December 20, 2000; accepted for publication on August 29, 2001; \\ presented by FERNANDO GALEMBECK
}

\begin{abstract}
Bioceramic composites were obtained from chitosan and hydroxyapatite pastes synthesized at physiological temperature according to two different syntheses approaches. Usual analytical techniques (X-ray diffraction analysis, Fourier transformed infrared spectroscopy, Thermo gravimetric analysis, Scanning electron microscopy, X-ray dispersive energy analysis and Porosimetry) were employed to characterize the resulting material. The aim of this investigation was to study the bioceramic properties of the pastes with nondecaying behavior from chitosan-hydroxyapatite composites. Chitosan, which also forms a water-insoluble gel in the presence of calcium ions, and has been reported to have pharmacologically beneficial effects on osteoconductivity, was added to the solid phase of the hydroxyapatite powder. The properties exhibited by the chitosan-hydroxyapatite composites were characteristic of bioceramics applied as bone substitutes. Hydroxyapatite contents ranging from 85 to $98 \%$ (w/w) resulted in suitable bioceramic composites for bone regeneration, since they showed a non-decaying behavior, good mechanical properties and suitable pore sizes.
\end{abstract}

Key words: bioceramic, chitosan, hydroxyapatite, composites, bone regeneration.

\section{INTRODUCTION}

Calcium phosphate based bioceramics have recently received special attention as bone replacement materials, as they behave similarly to the mineral constituent of bones (Martin and Brown 1995, Felício-Fernandes and Laranjeira 2000, Pereira et al. 1999, Kawachi et al. 2000, Shareef et al. 1993, Sivakumar et al. 1996).

Among their most attractive properties, these materials have shown no local or system toxicity, no response to strange bodies or inflammation, and apparent ability to attach themselves to host tissues (Kawachi et al. 2000). The mechanism of tissue attachment is directly related to the type of tissue

Correspondence to: Mauro C.M. Laranjeira

E-mail: mauro@qmc.ufsc.br response at the implant interface (Hench 1991). Implants always elicit a response from living tissues (Hench 1991), since replacement materials in living tissues are never inert.

Pores larger than $100 \mu \mathrm{m}$ are ideal for bioceramics (Kawachi et al. 2000), as they maintain vascularity and long-term viability (Hench 1991). In order to form macro porous biomaterials (pore size ranging from 50 to $250 \mu \mathrm{m}$ ) a polymer or organic substance is mixed to a powder material. Alternatively, it can be wetted with hydrogen peroxide that decomposes releasing oxygen gas to form pores (Kawachi et al. 2000). In the present work, the use of aluminum powder in alkaline media to form hydrogen gas is discussed.

Different calcium phosphate phases can 
be used depending whether a resorbable or bioactive material is desired (Hench 1991). The stability of calcium phosphate phases depends considerably upon temperature and moisture, either during processing or use.

HAp $\left[\mathrm{Ca}_{10}\left(\mathrm{PO}_{4}\right)_{6}(\mathrm{OH})_{2}\right]$ is the main inorganic constituent of human and animal bones and teeth. It has a $\mathrm{Ca} / \mathrm{P}$ ratio of 1.67 and water contents of 1.79 wt.\%.

The resorption and biodegradation of phosphate ceramics are caused by (1) physiochemical dissolution; (2) physical disintegration into small particles due to preferential chemical attack of grain boundaries; and (3) biological factors, such as phagocytes, which decreases local $\mathrm{pH}$ (Hench 1991).

The synthesis of calcium phosphate has been accomplished by different methods, including: precipitation in aqueous solutions, solid-state reactions, hydrothermal methods (Kawachi et al. 2000), (Hench 1991), sol-gel process and, more recently, micro emulsion (Kawachi et al. 2000). The phosphates can be transformed into biocompatible and osteoconductor ceramics, capable of inducing bone growth both on the surface and through the pores of the material (Kawachi et al. 2000, Hench 1991).

Chitosan, a poly-2-amino-2-deoxy- $\beta$ - $(1,4)-\mathrm{D}$ glucopyranose, is derived from chitin, poly-2-acetamide-2-deoxy- $\beta$-(1,4)-D-glucopyranose (Knaul et al. 1999). Chitin is one of the most abundant natural polysaccharides, primarily obtained as a subproduct of seafood. Chitosan has been used as a flocculent and adsorbent in wastewater treatment. Recently it has been applied in the biomedical and pharmaceutical areas, mainly because of its biodegradability, low toxicity, and good biocompatibility (Kawachi et al. 2000, Tas 2000).

The HAp-chitosan combination can be used to prepare composites with controlled bioactivity (biodegradability). Chitosan is insoluble in water and, consequently, in physiological environments. HAp can act as a reticular modifier agent (due to the presence of calcium and phosphorous) and its use as bone former (Felício-Fernandes and Laranjeira 2000), has also been appraised. Its superior osteoconductive properties render HAp a vast potential to be used in implants as bone substitute (Sivakumar et al. 1996).

In the present paper, we report the preparation and characterization of bioceramic composites in the form of pastes from hydroxyapatite and chitosan. This work also examines the probable interaction between amine group of chitosan and phosphate of hydroxyapatite. The chemical combination of chitosan and hydroxyapatite by the employed methods yielded a new material, which could be used as alternative bioceramic in the bone regeneration.

\section{EXPERIMENTAL}

\section{Materials AND METHODS}

A $0.16 \mathrm{~mol} / \mathrm{L}\left(\mathrm{NH}_{4}\right)_{2} \mathrm{HPO}_{4}$ solution was dripped into a stirred solution of $0.40 \mathrm{~mol} / \mathrm{L} \mathrm{Ca}\left(\mathrm{NO}_{3}\right)_{2}$ heated to $60^{\circ} \mathrm{C}$. The $\mathrm{pH}$ was maintained at 8.0 with dilute $\mathrm{NH}_{4} \mathrm{OH}$ solution. The mixture was then aged and vigorously stirred at its boiling point for about 2 hours. HAp precipitates were filtered, washed three times with distilled water, and dried overnight at $80^{\circ} \mathrm{C}$. The material was subsequently crushed into a powder. Pastes of various compositions were then prepared (Table I) from the HAp powder using a 4\% chitosan solution. Alternatively, an in situ route was also carried out from the reaction between synthesized Tricalciumphosphate (TCP), dehydrated dicalcium phosphate, chondroitin sulfate and sodium succinate, forming HApIII. The resulting HAp powder was also transformed into pastes using a $4 \%$ chitosan solution. After filling a bottomless syringe $1 \mathrm{~cm}$ in diameter, the paste was injected into a 2.0 $\mathrm{mol} / \mathrm{L} \mathrm{NaOH}$ solution to form non-decayed pastilles. The pastilles were washed at physiological $\mathrm{pH}$ and immersed for 24 hours in a physiological solution at $37^{\circ} \mathrm{C}$, following by 7 days immersed synthetic body fluid (SBF) prepared according to the method described by Tas (Tas 2000). SBF are known to be metastable buffer solutions, and even a small, undesired variance in both of the preparation steps and 
the storage temperatures, may drastically affect the phase purity and high-temperature stability of the produced HAp powders, as well as the kinetics of the precipitation processes.

\section{TABLE I}

Compositions of the prepared HApChitosan pastes

\begin{tabular}{c|c|c}
\hline Samples & \% HAp & \% Chitosan \\
\hline I & 55.6 & 44.4 \\
\hline II & 71.4 & 28.6 \\
\hline III & 86.2 & 13.8 \\
\hline IV & 93.1 & 6.90 \\
\hline V & 96.2 & 3.80 \\
\hline VI & 98.0 & 2.00 \\
\hline
\end{tabular}

$\mathrm{NaCl}(99.5 \%), \mathrm{NaHCO}_{3}$ (99.5\%), $\mathrm{KCl}(99.0 \%)$, $\mathrm{Na}_{2} \mathrm{HPO}_{4} \cdot 2 \mathrm{H}_{2} \mathrm{O}$ (99.5\%), $\mathrm{MgCl}_{2} \cdot 6 \mathrm{H}_{2} \mathrm{O}$ (99.0\%), $\mathrm{CaCl}_{2} \cdot \mathrm{H}_{2} \mathrm{O}$ (99.0\%), $\mathrm{Na}_{2} \mathrm{SO}_{4}, \quad\left(\mathrm{CH}_{2} \mathrm{OH}\right)_{3} \mathrm{CNH}_{2}$ $(99.5 \%)$, and $\mathrm{HCl}$ (37 vol\%, ) were used in the preparation of the SBF (Tas 2000).

\section{TABLE II}

The shifts observed at the FTIR spectra of the characteristic bands from the functional groups

\begin{tabular}{c|c|c|c}
\hline & \multicolumn{3}{|c}{ Wave number $\left(\mathrm{cm}^{-1}\right)$} \\
\hline Samples & $\mathrm{PO}_{4}^{3-}$ & Amine & $\mathrm{OH}^{-}$ \\
\hline HAp100 & $566 ; 1034$ & - & 3444 \\
\hline HApIII & $564 ; 1034$ & - & 3442 \\
\hline Chitosan & - & $2922 ; 1380$ & 3444 \\
\hline I & $566 ; 1034$ & $2080 ; 1422$ & 3458 \\
\hline III & $564 ; 1032$ & $2080 ; 1422$ & 3450 \\
\hline V & - & $-; 1652$ & 3440 \\
\hline VI & - & $-; 1640$ & 3448 \\
\hline
\end{tabular}

The pastilles were then freeze-dried and characterized by conventional analytical techniques. In order to enhance the porosity, HAp powder was mixed with aluminum powder $(0.3-1.1 \%)$, and then transformed into paste. Due to the toxicity of aluminum, all the metal was eliminated by dissolution in $2 \mathrm{~mol} / \mathrm{L} \mathrm{NaOH}$ solution, after immersing the pastilles in the alkaline solution. This resulted in the formation of sodium aluminate in solution and hydrogen gas, which led to the forming of pore at the order larger than $100 \mu \mathrm{m}$. The sodium aluminate was removed by extensive washing with deionized water. The resulting pastilles after immersed for 7 days in synthetic body fluid (SBF) at $37^{\circ} \mathrm{C}$ (Tas 2000) were also characterized by conventional analytical techniques.

All samples were freezes-dried and characterized by the following techniques: Infrared absorption spectroscopy using $\mathrm{KBr}$ pellets (FTIR); $\mathrm{X}$ rays powder diffraction (XRD); Scanning electronic microscopy (SEM), where the pastille surfaces were covered with a thin layer of gold; Analysis of X rays dispersive energy (EDX); Porosimetry by mercury intrusion; and TG analysis of powder of composites (TGA).

\section{RESULTS AND DISCUSSION}

Table I shows the compositions, which resulted in the desired characteristics. HAp contents ranging from 85 to 98 wt.\% was suitable to obtain pastilles. The FTIR data that is presented later in this report suggest that there is an association between chitosan and the phosphate ions that may be crosslinking the chitosan chains. Table II shows the characteristic bands of the material's functional groups seen in Figure 1, i.e., amine from chitosan and phosphate from HAp. Figure 1 shows a comparison between FTIR spectra on (a) chitosan, (b) HAp100, (c) HApIII, (d) composite I, (e) composite III, (f) composite V, and (g) composite VI. The spectrum of chitosan (Fig. 1a) exhibits characteristic bands at 2922 and $1380 \mathrm{~cm}^{-1}$ due to the protonated amine stretch and deformation vibrations. The spectra of HAp100 and HApIII (Figure 1b and 1c) exhibit characteristic bands at 566 and 1034, 564 and $1034 \mathrm{~cm}^{-1}$ attributed to the phosphate stretch and deformation vibrations. The shift of the characteristic bands of these functional 


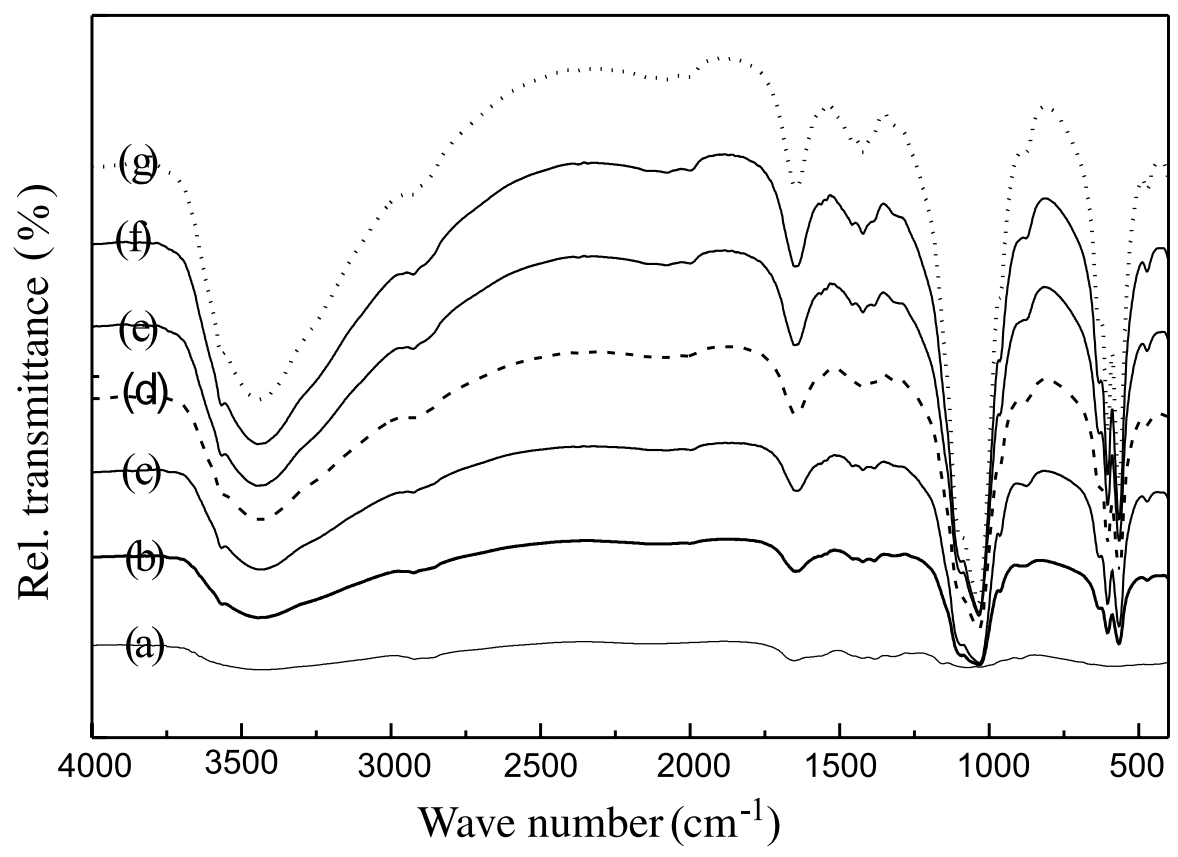

Fig. 1 - FTIR spectra from: (a) Chitosan, (b) HAp100, (c) HApIII, (d) composite I, (e) composite III, (f) composite V, and (g) composite VI.

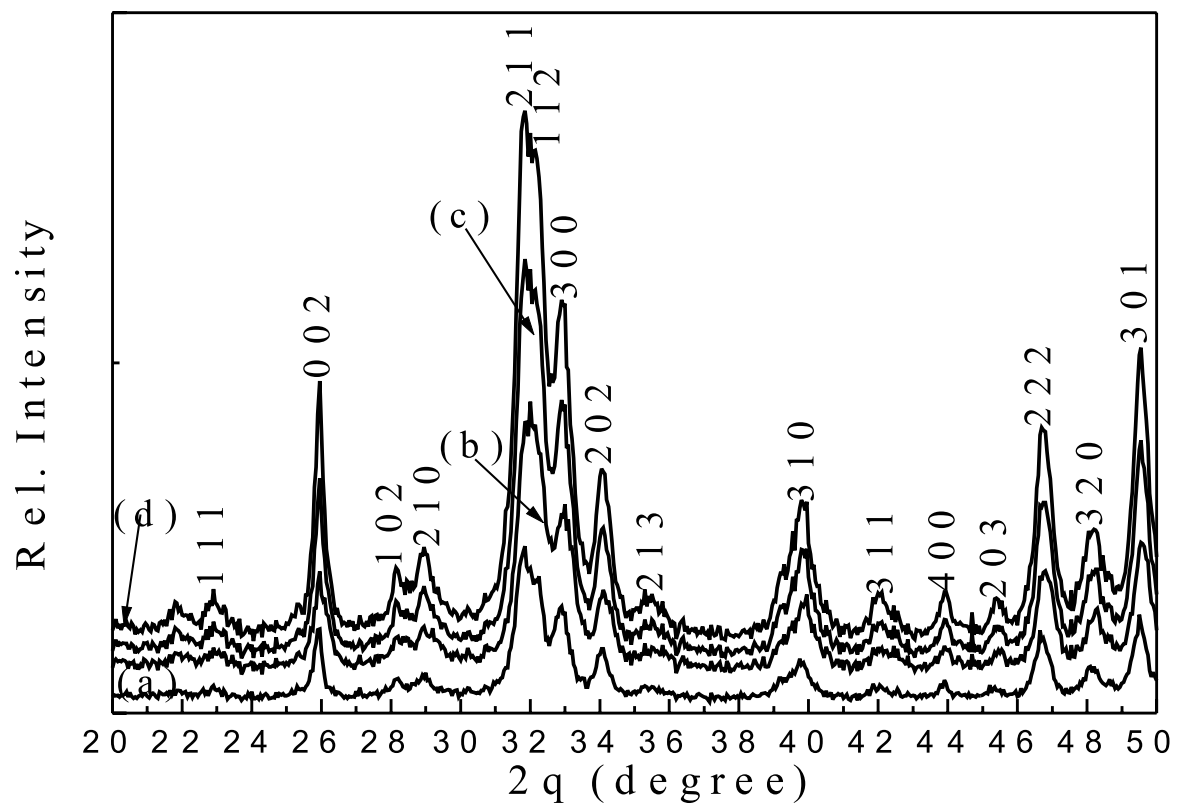

Fig. 2 - XRD patterns of powders (a) composite V, (b) composite II, (c) HAp100, and (d) HApIII. 
groups (protonated amine and phosphate) to lower wave number (2080 and $1422 \mathrm{~cm}^{-1}$ for composites I and III, and 1652, $1640 \mathrm{~cm}^{-1}$ for composites V and VI respectively) was observed in Figure $1 \mathrm{~d}-1 \mathrm{~g}$ for the functional group of chitosan, and may be attributed to interactions involving these groups. The shift of the characteristic bands of phosphate group was only observed on the FTIR spectrum of composite VI in Figure 1g.

The XRD patterns shown in Figure 2 reveal that the method used to synthesize HAp100 resulted in better crystallinity (Figure 2c.), compared to the in situ approach (HApIII in Figure 2b). In addition, powder samples from bioceramic composites (Figure $2 \mathrm{a}$ and $2 \mathrm{~d}$ ) were similar to those representatives of HAp100 (Figure 2c).

A morphological study (Figure 3) was also carried out and showed that composites prepared from HAp100 (Figure 3a, 3b, 3d, 3e) had quite porous surfaces, exceeding the porosity present on those from HApIII as showed in Figure 3c. This was probably due to the uniform grain distribution observed from HAp100. Additional, using aluminum $(0.2-0.5$ wt.\%) results in pores in excess of $100 \mu \mathrm{m}$ in average diameter (Figure 3f).

TG plots are shown in Figure 4. It can be seen that no phase transformation took place upon heating HAp100 (Figure 4e) or HApIII (Figure 4d). There is no notable occurrence of weight loss in both HAp products. The weight loss observed from chitosan at $281.01^{\circ} \mathrm{C}$ and $295.89^{\circ} \mathrm{C}$ (Figure $4 \mathrm{a}$ ), probably corresponded to the decomposition and elimination of the polymeric constituent. Bioceramic composites showed in Figure $4 \mathrm{~b}$ and $4 \mathrm{c}$ weight loss at higher temperature $\left(298.27^{\circ} \mathrm{C}\right.$ and $307.08^{\circ} \mathrm{C}$ respectively). The weight loss observed at $281.01^{\circ} \mathrm{C}$ in the thermograph of chitosan disappeared in those of the composites I and III (Figure 4b and 4c, respectively). This confirmed the hypothesis of interactions between the functional amine groups from chitosan and phosphate groups from HAp. The amplitude of the temperature shift observed was inversely proportional to the chitosan contents present in the bioceramic sample. The compressive strength of bio- ceramic pastilles varied from 3-7 MPa, where the compositions with hydroxyapatite contents ranging from 85 to 98 wt.\% showed the highest values.

An analysis of the $X$ ray dispersive energy pattern shown in Figure 5 revealed the absence of residual aluminum in the bioceramic composite. All aluminum was eliminated due to its toxicity by dissolution in $2 \mathrm{~mol} / \mathrm{L} \mathrm{NaOH}$ solution.

Both methods used to synthesize HAp were efficient, since the resulting bioceramic composites showed certain porosity and crystallinity. The composites presented pore sizes larger than $100 \mu \mathrm{m}$, which is the requirement for the bone ingrowths through the pore channels. The techniques used to prepare bioceramics from calcium phosphate and chitosan biopolymer led to the preparation of materials with the necessary requirements for bone regeneration: inhibition of decay of the pastilles in body fluids, suitable pore sizes and mechanical resistance.

We recommend the composites with hydroxyapatite contents ranging from 85 to $98 \mathrm{wt} \%$ for the production of ceramic pastilles, since decay of the paste was effectively inhibited at this composition range, which also demonstrated the highest mechanical properties. In vivo evaluation of these HAp-Chitosan composites is awaited based on this initial in vitro study.

\section{RESUMO}

Compósitos biocerâmicos foram obtidos a partir de pastas de quitosana e hidroxiapatita, preparadas a temperatura fisiológica seguindo dois métodos diferentes de síntese. As técnicas analíticas usuais (Análise de difração de raios-X, Espectroscopia de absorção no infravermelho com transformada de Fourier, Análise termogravimétrica, Microscopia eletrônica de varredura, Análise por energia dispersiva de raios- $X$, e Porosimetria) foram empregadas para caracterizar o material resultante. O objetivo deste trabalho foi estudar as propriedades biocerâmicas das pastas relativas ao comportamento de não-desintegração dos compósitos de quitosana-hidroxiapatita. A quitosana, que também forma um gel insolúvel em água na presença de 


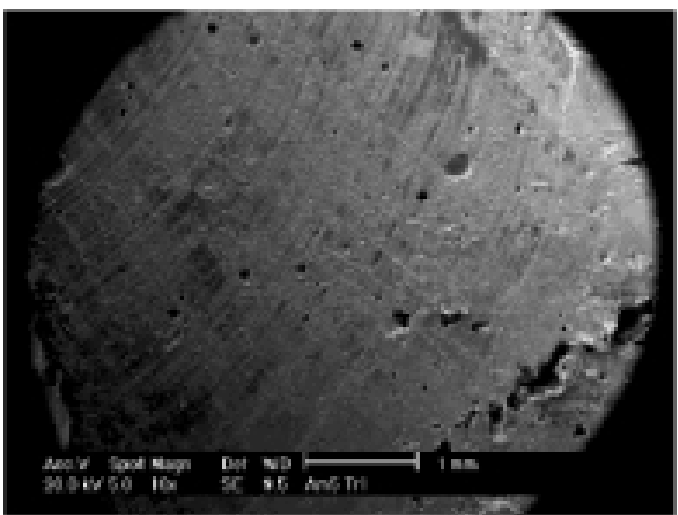

(a)

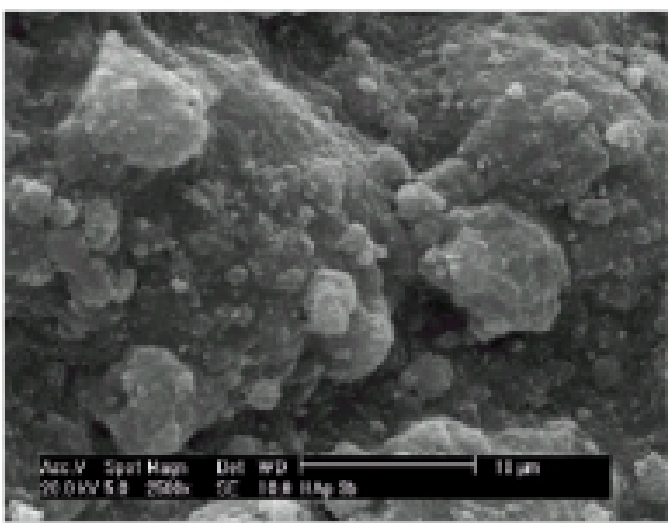

(c)

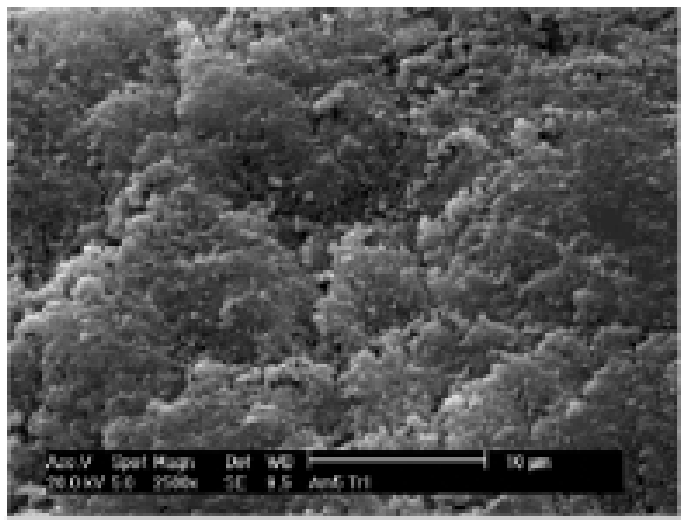

(e)

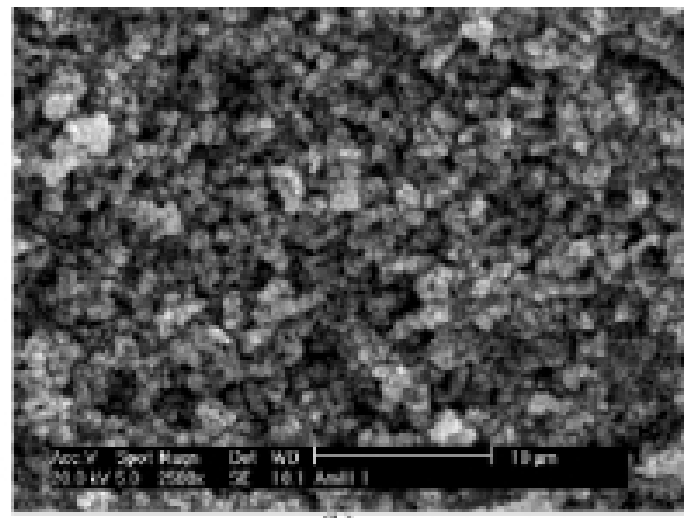

(b)

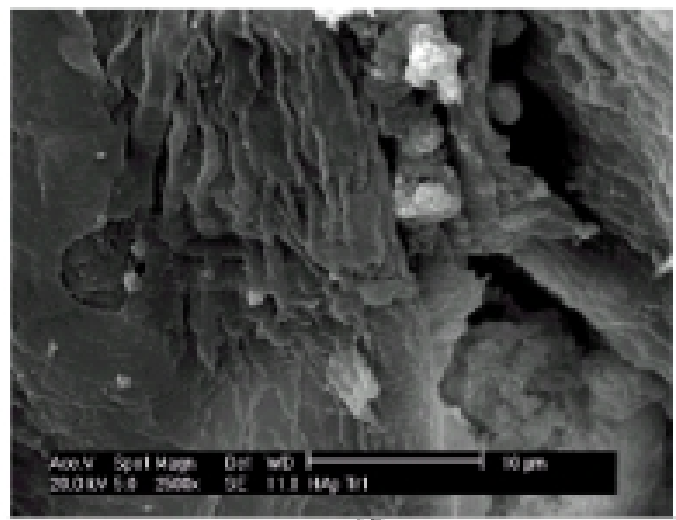

(d)

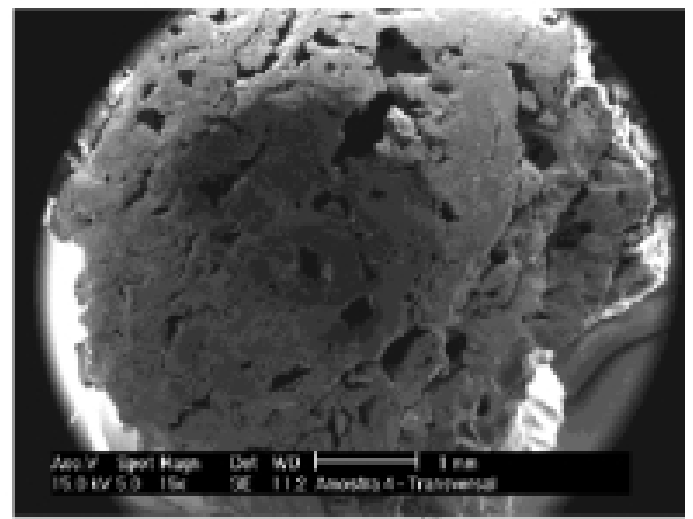

(t)

Fig. 3 - SEM micrograph results from: (a) composite V, (b) composite III, (c) composite III (from HApIII), (d) composite I transversal section, (e) composite V transversal section, and (f) composite IV transversal section (with $0.3 \%$ Aluminum addition).

íons cálcio, e tem mostrado possuir efeitos farmacologicamente benéficos na condutividade óssea, foi adicionada à fase sólida do pó de hidroxiapatita. As propriedades exibi- das pelos compósitos de quitosana-hidroxiapatita apresentaram características de biocerâmicas empregadas como substitutos de osso. O conteúdo de hidroxiapatita na faixa 


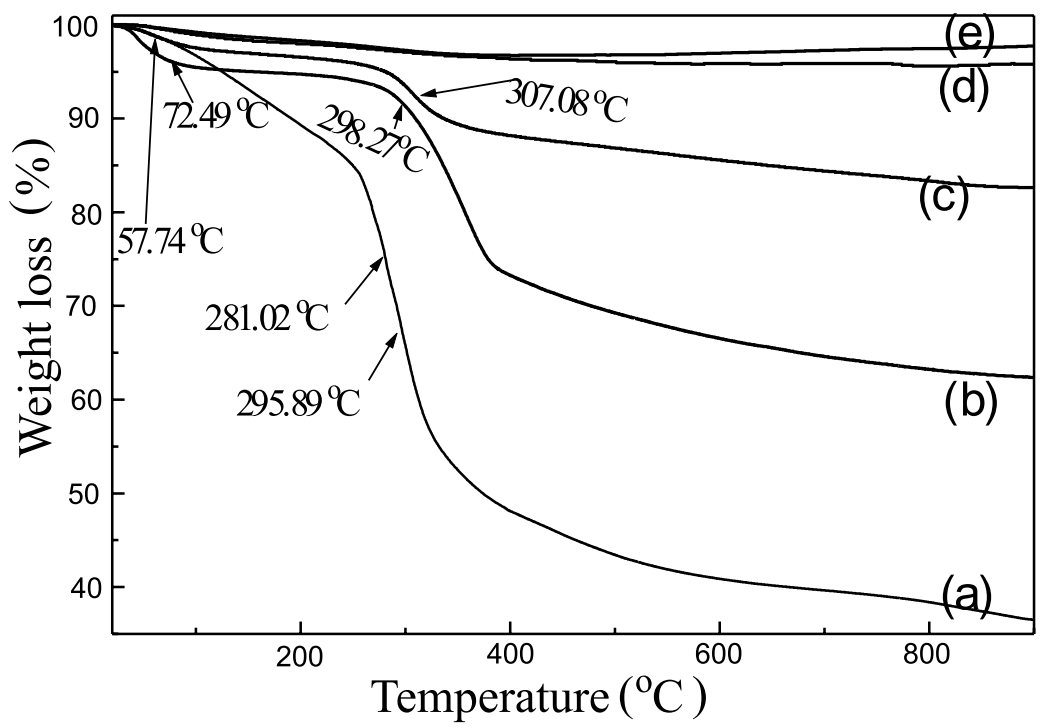

Fig. 4 - Thermographs from sample of: (a) Chitosan, (b) composite I, (c) composite III, (d) HApIII, and (e) HAp100.

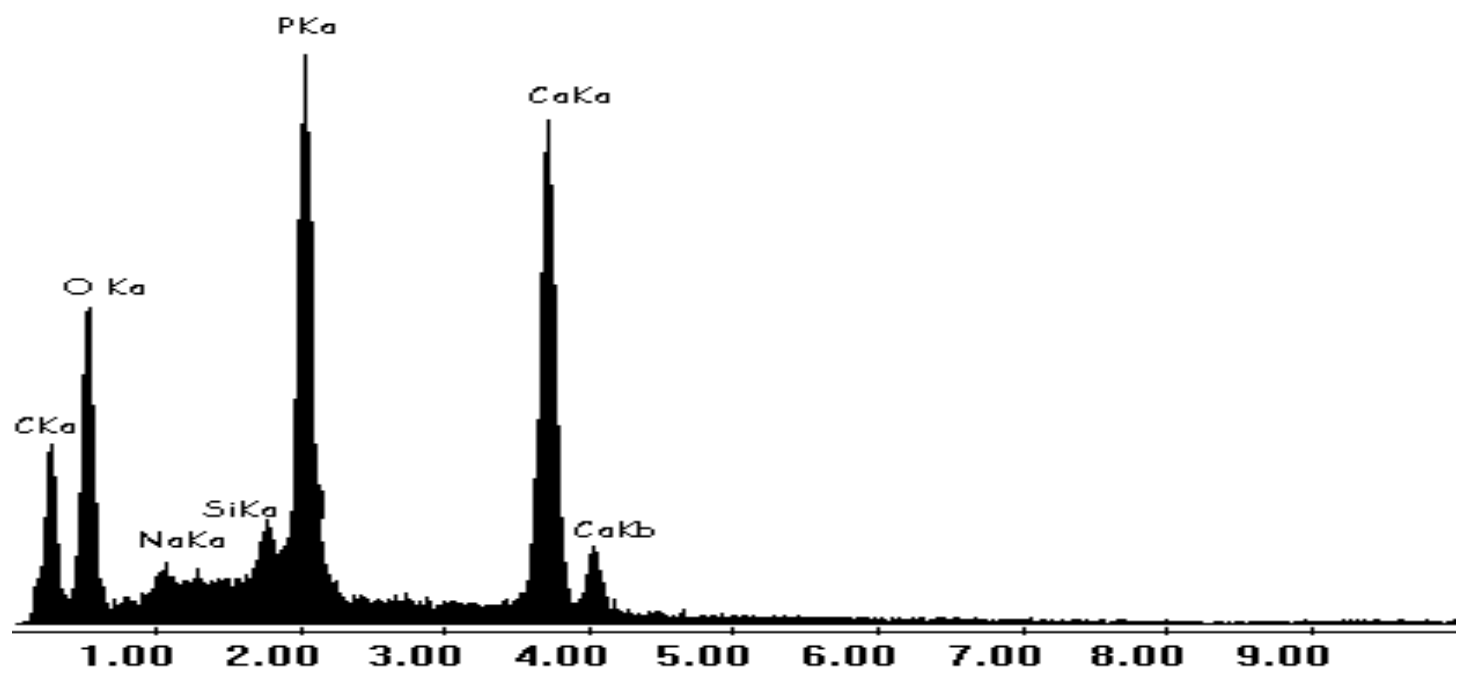

Fig. 5 - X ray dispersive energy pattern from sample of: composite IV.

entre 85 a 98\% em peso resultou em compósitos biocerâmicos adequados para regeneração óssea, visto que apresentaram um comportamento de não-desintegração, boas propriedades mecânicas e tamanhos de poros apropriados.

Palavras-chave: biocerâmica, quitosana, hidroxiapatita, compósitos, regeneração óssea.

\section{REFERENCES}

Felício-Fernandes G and Laranjeira MCM. 2000. Calcium phosphate biomaterials from marine algae. Hydrothermal synthesis and characterization. Quim Nova 23: 441-446. 
Hench LL. 1991. Bioceramics: From Concept to Clinic. J Am Ceram Soc 74: 1487-1510.

Kawachi EY, Betran CA, dos Reis RR and Alves OL. 2000. Biocerâmicas: Tendências e Perspectivas de uma Área Interdisciplinar. Quim Nova 23: 518-522.

Knaul JZ, Hudson SM and Creber KAM. 1999. Improved Mechanical Properties of Chitosan Fibers. J Appl Polym Sci 72: 1721-1732.

Martin RI ANd Brown PW. 1995. Mechanical properties of Hydroxyapatite formed at Physiological Temperature. J Mater Sci: Mater Med 6: 138-143.

Pereira APV, Vasconcelos WL and Oréfice RL. 1999. Novos biomateriais: híbridos orgânicoInorgânicos bioativos. Polim: Cienc e Tecnol 9: 104109.
Shareef MY, Messer PF and van Noort R. 1993. Fabrication, Characterization and Fracture Study of a Machinable Hydroxyapatite Ceramic. Biomaterials 14: 69-75.

Sivakumar M, Sampath Kumar TS, Shantha KL and Panduranga Rao K. 1996. Development of Hydroxyapatite Derived from Indian Coral. Biomaterials 17: 1709-1714.

TAS AC. 2000. Synthesis of Biomimetic Ca-Hydroxyapatite powders at $37^{\circ} \mathrm{C}$ in Synthetic Body Fluids. Biomaterials 21: 1429-1438. 